J. Clin. Chem. Clin. Biochem.

Vol. 22, 1984, pp. 301-304

\title{
Reference Values of Various Blood Constituents in Young Minipigs
}

\author{
By T. Brechbühler'), M. Kaeslin and F. Wyler \\ University Children's Hospital Basle
}

(Received November 11, 1983/January 11, 1984)

Dedicated to Professor G. Stalder on the occasion of his 60th birthday

Summary: In the Göttinger minipig, the reference values of 18 parameters in whole blood or plasma were determined. The results are expressed both as the mean value and $\pm 2 \mathrm{SD}$ presuming a symmetrical normal distribution and as the median value with the corresponding range. For most blood constituents, the results of the two modes of calculation were similar. Comparison of the values from young minipigs with those from children shows that these animals are well suited in this respect for experimental work related to human medicine.

\section{Referenzwerte verschiedener Blutbestandteile beim jungen Miniaturschwein}

Zusammenfassung: Beim Göttinger Miniaturschwein wurden die Referenzwerte für 18 Kenngrößen im Vollblut oder Plasma ermittelt. Die Berechnungen erfolgten einerseits unter der Annahme einer symmetrischen Normalverteilung, andererseits als Medianwert und Angabe der Extremwerte. Bei den meisten Bestandteilen stimmen die Ergebnisse der beiden Berechnungsarten gut überein.

Der Vergleich der Werte von jungen Miniaturschweinen mit den entsprechenden Referenzwerten bei Kindern zeigt, daß diese Versuchstiere für viele humanmedizinische Untersuchungen geeignet sind.

\section{Introduction}

Reference values of chemical and other parameters of blood in the minipig can be found in the literature (1). However, mostly only small groups were described with multiple determinations in the same animal, and no detailed references were given to the analytical methods used. Furthermore, the site and circumstances of the puncture add to the variation, as shown in our laboratory with experiments on rabbits (2) and as shown by values from infants and children under stress. Particularly variable are the values of blood gases and of certain metabolites (e. g. lactate, pyruvate, free fatty acids, glucose etc.). This paper presents reference values obtained under strictly standardized conditions in 54 minipigs.

\section{Materials and Methods}

Animals and sample collection

Fifty four minipigs $(46 \%, 8 \delta)$ were used with an average age of $49(36-71)$ days and a mean weight of $3.2(2.23-4.95) \mathrm{kg}$. The animals were raised at the Institute for Veterinary Hygiene of the University of Zurich (3). At age 3 weeks they were weaned from the mother and transferred to our laboratory where they stayed for a further 2 weeks. They were fed at 7 a. m. and at 3.30 p.m. with $60 \mathrm{~g}$ of $407-$ Ferkelstarter (Klingentalmühle AG, Kaiseraugst) until they weighted $4 \mathrm{~kg}$, thereafter with $80 \mathrm{~g}$ of the same product. Drinking water was provided ad libitum. Under Halothane $/ \mathrm{O}_{2}$-anesthesia, polyvinyl catheters were inserted into various vessels for haemodynamic studies. On the $3 \mathrm{rd}-4$ th post operative day 4-41/2 hours after feeding, arterial blood samples were taken from the catheter in the right femoral artery. Whole blood $(5 \mathrm{ml})$ was collected in tubes containing Li-heparinate powder.

\footnotetext{
1) Partially supported by the Swiss National Science Foundation,
} Grant No. 3.115.77 and 3.802.0.80. 
Analytical methods

All the determinations were made with the same standard methods which are used for the patients in our hospital. The measurements of all series were submitted to the usual internal quality controls (primary or secondary standard and one or more control samples for the verification of accuracy and precision).

Piston pipets (Eppendorf, Lancer), Sanzpipets (Beckman) and semi automatic pipettors and dilutors (Hook \& Tucker, Molter) were employed. Photometric measurements were made on the LKB Absorptiometer 2074 or the photometer Eppendorf PCP 6121.

Description of methods

Sodium and potassium

Flame photometry with internal standard of Lithium (IL 243, Instrumentation Laboratory)

\section{Calcium and magnesium}

Absorption flame photometry after dilution with a solution of Lanthanum nitrate at $422.7 \mathrm{~nm}$ and $285.2 \mathrm{~nm}$, respectively (AAS 272, Perkin-Elmer).

\section{Chloride}

Coulometry in a solution of sulphuric acid using reagents prepared in our laboratory ( $\mathrm{Cl}-\mathrm{CO}_{2}$ Analyzer, Beckman).

\section{Inorganic phosphate}

Malachite green method with added urea (Kit 1023, Roche Diagnostica).

Glucose

Enzymatic method with glucose oxidase measuring $\mathrm{O}_{2}$ disappearance (Glucose Analyzer 1, Beckman).

\section{Creatinine}

Kinetic method with sodium picrate, reagents prepared in our laboratory (Creatinine Analyzer 2, Beckman).

\section{Urea}

Enzymatic method with urease, using the Berthelot reaction (Kit 124770, Boehringer).

\section{Cholesterol}

Enzymatic cholesterol oxidase/4-aminoantipyrine (CHOD-PAP) method (Kit 290319, Boehringer).

\section{Triglycerides}

Saponification with $\mathrm{KOH}$ and enzymatic determination of glycerol (Kit 125032, Boehringer).

Protein, total

Photometry of biuret reaction (Kit 1008, Roche Diagnostica).

\section{Albumin}

Electrophoresis on cellulose acetate (Cellogel), staining with red Ponceau S, measurement on Eppendorf photometer at $546 \mathrm{~nm}$ and integrating recorder $W+W 4201$.

\section{Osmolarity}

Decrease of freezing point (Halbmikro-Osmometer, Knauer).

pH

Glass electrode, AVL 960. All values were corrected for the actual body temperature of the animal.

$\mathrm{pCO}_{2}$

$\mathrm{CO}_{2}$ gas electrode, AVL 960. All values were corrected for the actual body temperature of the animal.

\section{Standard bicarbonate}

Calculated. All values were corrected for the actual body temperature of the animal.

\section{Haematocrit}

Micromethod, centrifugation of blood samples in glass capillaries for $5 \mathrm{~min}$ (Adams Autocrit centrifuge (Becton \& Dickinson).

\section{Results}

The 18 reference parameters are listed in table 1. The mean value and the standard deviations are presented assuming a Gaussian distribution, but median values and the full range are also listed. Differences between sexes were not observed (Wilcoxontest not significant).

Table 2 shows the day to day imprecision of the different methods $\left(\mathrm{s}_{\mathrm{m}}\right)$ in comparison with the variation of the reference values (s). The last column shows the quotient $2 \mathrm{~s}$ divided by $\mathrm{s}_{\mathrm{m}}$.

\section{Discussion}

Blood sampling by catheter from an undisturbed animal is certainly the best method to obtain reference values representative of basal physiological conditions (4).

The greatest difference between the mean and median was seen in the urea and triglycerides values, where the standard deviation $\left(s_{m}\right)$ from methodological day to day imprecision reached $2 \mathrm{~s}_{\mathrm{m}}$. All other values were within one $s_{m}$ or less. Since the $\pm 2 s$ values for virtually all parameters are within the full range, we can assume a symmetrical distribuition around the mean. Phosphate and magnesium show upper ranges above the $2 \mathrm{~s}_{\mathrm{m}}$ value; for glucose and urea there are extreme values which deviate more than $2 s_{m}$ from the $\pm 2 \mathrm{~s}$ ranges." 
Tab. 1. Reference values in plasma or whole blood from minipigs.

\begin{tabular}{|c|c|c|c|c|c|c|c|c|}
\hline & & $\mathbf{N}$ & $\overline{\mathbf{x}}$ & $-2 \mathrm{~s}$ & $+2 s$ & Median & Range & \\
\hline Sodium & $\mathrm{mmol} / \mathrm{l}$ & 53 & 142.3 & 136.3 & -148.3 & 142 & 137 & -149 \\
\hline Potassium & $\mathrm{mmol} / \mathrm{l}$ & 54 & 3.94 & 3.30 & -4.57 & 4.0 & 3.3 & -4.7 \\
\hline Calcium & $\mathrm{mmol} / \mathrm{l}$ & 53 & 2.58 & 2.26 & $-\quad 2.90$ & 2.60 & 2.24 & $-\quad 2.90$ \\
\hline Magnesium & $\mathrm{mmol} / \mathrm{l}$ & 54 & 0.753 & 0.605 & $5-\quad 0.901$ & 0.75 & 0.60 & $-\quad 0.95$ \\
\hline Chloride & $\mathrm{mmol} / \mathrm{l}$ & 52 & 101.3 & 94.1 & -108.5 & 101.0 & 93.8 & -109.5 \\
\hline$P_{i}$ & $\mathrm{mmol} / \mathrm{l}$ & 53 & 1.61 & 1.02 & $-\quad 2.20$ & 1.58 & 1.06 & $-\quad 2.44$ \\
\hline Glucose & $\mathrm{mmol} / \mathrm{l}$ & 53 & 5.98 & 3.95 & - 7.99 & 5.94 & 2.61 & -8.72 \\
\hline Creatinine & $\mu \mathrm{mol} /$ & 52 & 52.2 & 30.2 & -74.2 & 52.1 & 29.0 & -73.0 \\
\hline Urea & $\mathrm{mmol} / \mathrm{l}$ & 53 & 3.19 & 0.90 & $-\quad 5.48$ & 3.09 & 1.15 & -6.43 \\
\hline Cholesterol & $\mathrm{mmol} / \mathrm{l}$ & 29 & 1.65 & 0.90 & -2.40 & 1.70 & 0.83 & $-\quad 2.46$ \\
\hline Triglycerides & $\mathrm{mmol} / 1$ & 27 & 0.195 & 0.010 & $0-\quad 0.380$ & 0.16 & 0.05 & $-\quad 0.40$ \\
\hline Protein, total & $\mathrm{g} / \mathrm{l}$ & 52 & 54.0 & 44.7 & -63.2 & 54.0 & 45.0 & -64.0 \\
\hline Albumin & $g / 1$ & 41 & 26.2 & 20.1 & -32.3 & 25.8 & 19.7 & -33.4 \\
\hline Osmolarity & mosmol/1 & 50 & 283.5 & 263.2 & -303.8 & 285 & 265 & -315 \\
\hline $\mathrm{pH}^{*}$ & & 54 & 7.443 & 7.384 & $4-\quad 7.502$ & 7.444 & 7.390 & $-\quad 7.515$ \\
\hline $\mathrm{pCO}_{2}{ }^{\circ}$ & $\mathrm{kPa}$ & 54 & 5.04 & 4.13 & -5.96 & 5.08 & 4.01 & $-\quad 5.87$ \\
\hline Stand. bicarbonate & $\mathrm{mmol} / \mathrm{l}$ & 52 & 25.4 & 21.1 & -29.7 & 25.5 & 20.5 & -29.4 \\
\hline Haematocrit & & 52 & 0.33 & 0.25 & $-\quad 0.40$ & 0.32 & 0.25 & -0.42 \\
\hline
\end{tabular}

- corrected for the body temperature of the animal

$\mathrm{pH}, \mathrm{pCO}_{2}$, standard bicarbonate and haematocrit were measured in whole blood, all other parameters in plasma.

Tab. 2. Comparison of the methodological variation with the variation of references values".

\begin{tabular}{|c|c|c|c|c|c|c|}
\hline & & \multicolumn{2}{|c|}{ Error of method } & \multicolumn{3}{|c|}{ Range for animal } \\
\hline & & $-2 s_{m}$ & $+2 s_{m}$ & $-2 s$ & $+2 s$ & $2 \mathrm{~s} / \mathrm{s}_{\mathrm{m}}$ \\
\hline Sodium & $\mathrm{mmol} / 1$ & 141.2 & 143.4 & 136.3 & 148.3 & 11.3 \\
\hline Potassium & $\mathrm{mmol} / \mathrm{l}$ & 3.84 & 4.04 & 3.30 & 4.57 & 12.8 \\
\hline Calcium & $\mathrm{mmol} / \mathrm{l}$ & 2.48 & 2.68 & 2.26 & 2.90 & 6.4 \\
\hline Magnesium & $\mathrm{mmol} / \mathrm{l}$ & 0.736 & 0.770 & 0.605 & 0.901 & 17.4 \\
\hline Chloride & $\mathrm{mmol} / \mathrm{l}$ & 98.4 & 104.2 & 94.1 & 108.5 & 5.0 \\
\hline $\mathbf{P}_{\mathbf{i}}$ & $\mathrm{mmol} / \mathrm{l}$ & 1.51 & 1.71 & 1.02 & 2.20 & 11.8 \\
\hline Glucose & $\mathrm{mmol} / \mathrm{l}$ & 5.84 & 6.12 & 3.95 & 7.99 & 29.0 \\
\hline Creatinine & $\mu \mathrm{mol} / 1$ & 50.2 & 54.2 & 30.2 & 74.2 & 22.4 \\
\hline Urea & mmol/! & 3.08 & 3.30 & 0.90 & 5.48 & 41.6 \\
\hline Cholesterol & $\mathrm{mmol} / \mathrm{I}$ & 1.48 & 1.82 & 0.90 & 2.40 & 8.8 \\
\hline Triglycerides & $\mathrm{mmol} / \mathrm{l}$ & 0.157 & 0.233 & 0.010 & 0.380 & 9.7 \\
\hline Protein, total & $\mathrm{g} / 1$ & 52.4 & 55.6 & 44.7 & 63.2 & 11.6 \\
\hline Albumin & $\mathrm{g} / \mathrm{l}$ & 23.9 & 28.5 & 20.1 & 32.3 & 5.3 \\
\hline Osmolarity & mosmolnol/1 & 273.8 & 293.2 & 263.2 & 303.8 & 4.2 \\
\hline $\mathrm{pH}$ & & 7.413 & 7.473 & 7.384 & 7.502 & 3.9 \\
\hline $\mathrm{pCO}_{2}$ & $\mathrm{kPa}$ & 4.47 & 5.61 & 4.13 & 5.96 & 3.2 \\
\hline Stand. bicarbonate & mmol/1 & 22.4 & 28.4 & 21.1 & 29.7 & 2.9 \\
\hline Haematocrit & & 0.29 & 0.37 & 0.25 & 0.40 & 4.0 \\
\hline
\end{tabular}

- the corresponding mean values are listed in table 1 .

Analysis of individual results shows that magnesium has one value and phosphate two values which lie outside the $2 s_{m}$ range. Glucose has one value below and one above this limit. Urea, however, shows 3 measurements above $2 \mathrm{~s}_{\mathrm{m}}$, so that the median and full range values may be preferable for the assessment of parameters. For all other parameters the means $\pm 2 \mathrm{~s}$ are interchangeable with the non-parametric presentation. Possible variability caused by the analytical error is seen for osmolarity, $\mathrm{pH}$ and blood gases and haematocrit. Nevertheless the wide range seen in our values correspond well with those found in the literature. 
With respect to the use of the minipig as an experimental animal for human pathophysiology, a comparison with similar reference values from children (tab. 3) seems appropriate $(5,6,7)$.

Tab. 3. Reference ranges of children in comparison with those of minipigs.

\begin{tabular}{|c|c|c|c|c|c|}
\hline \multirow[b]{2}{*}{ Sodium } & \multirow[b]{2}{*}{$\mathrm{mmol} / \mathrm{l}$} & \multicolumn{2}{|c|}{$\begin{array}{l}\text { Children } \\
1-3 a\end{array}$} & \multicolumn{2}{|c|}{$\begin{array}{l}\text { Minipigs } \\
36-71 d\end{array}$} \\
\hline & & 132 & -145 & 136.3 & -148.3 \\
\hline Potassium & $\mathrm{mmol} / \mathrm{l}$ & 3.8 & $-\quad 5.5$ & 3.30 & -4.57 \\
\hline Calcium & $\mathrm{mmol} / 1$ & 2.3 & $-\quad 2.7$ & $2.26-$ & $-\quad 2.90$ \\
\hline Magnesium & $\mathrm{mmol} / 1$ & 0.68 & $3-\quad 0.88$ & 0.605 & $5-\quad 0.901$ \\
\hline Chloride & $\mathrm{mmol} / \mathrm{l}$ & 96 & -110 & 94.1 & -108.5 \\
\hline$P_{i}$ & $\mathrm{mmol} / \mathrm{l}$ & 0.9 & $-\quad 1.7$ & 1.02 & $-\quad 2.20$ \\
\hline Glucose & $\mathrm{mmol} / \mathrm{l}$ & 4.1 & $-\quad 5.9$ & 3.95 & - 7.99 \\
\hline Creatinine & $\mu \mathrm{mol} / \mathrm{l}$ & 27 & -71 & 30.2 & -74.2 \\
\hline Urea & $\mathrm{mmol} / \mathrm{l}$ & 4.0 & -6.5 & 1.15 & -6.43 \\
\hline Cholesterol & $\mathrm{mmol} / \mathrm{l}$ & 3.1 & $-\quad 5.8$ & 0.90 & -2.40 \\
\hline Triglycerides & $\mathrm{mmol} / \mathrm{l}$ & 0.83 & $-\quad 1.93$ & 0.010 & $-\quad 0.380$ \\
\hline Protein, total & $g / 1$ & 63 & -71 & 44.7 & -63.2 \\
\hline Albumin & $g / 1$ & 36 & -51 & 20.1 & -32.3 \\
\hline Osmolarity & $\mathrm{mosmol} / \mathrm{l}$ & 280 & -300 & 263.2 & -303.8 \\
\hline $\mathrm{pH}$ & & 7.37 & $-\quad 7.43$ & 7.384 & $7-\quad 7.502$ \\
\hline $\mathrm{pCO}_{2}$ & $\mathrm{kPa}$ & $4.01-$ & $-\quad 5.00$ & 4.13 & $-\quad 5.96$ \\
\hline $\begin{array}{l}\text { Stand. } \\
\text { bicarbonate }\end{array}$ & $\mathrm{mmol} / \mathrm{l}$ & 20 & -25 & 21.1 & -29.7 \\
\hline Haematocrit & & 0.30 & $-\quad 0.41$ & 0.25 & $-\quad 0.40$ \\
\hline
\end{tabular}

Phosphate, glucose, $\mathrm{pH}, \mathrm{pCO}_{2}$ and standard bicarbonate show higher values, whereas urea, protein, albumin, cholesterol, triglycerides and haematocrit exhibit lower values. All remaining parameters are similar to those found in children. The differences could be explained partly by the food uptake and also by the effect on metabolism of the rapid growth of these minipigs.

Analysis of the food uptake by minipigs and children is summarized in table 4 .

Tab. 4. Food uptake $\mathrm{g} / \mathrm{d} \cdot \mathrm{kg}$ bódy weight.

\begin{tabular}{llll}
\hline & Proteins & Lipids & $\begin{array}{l}\text { Carbo- } \\
\text { hydrates }\end{array}$ \\
\hline Minipigs $^{*}$ & $6.2-11.0$ & $2.3-4.2$ & $13.4-23.8$ \\
Children * $^{*}$ & $1.2-2.2$ & $1.3-2.4$ & $5.8-10.6$ \\
\hline
\end{tabular}

- calculated from food composition indicated by the manufacturer.

*. FAO/WHO and Deutsche Gesellschaft für Enrnährung.

The parameters of clinical chemistry as an expression of physiology in minipigs (and pigs) are closer to man than any animal species examined up to now with exception of the primates.

\section{Acknowledgements}

We are grateful to Miss Gamper for technical assistance and Mr. Fischbach and the laboratory team of clinical chemistry for the multiple analysis of samples.

\title{
References
}

1. Glodek, P. \& Oldigs, B. (1981) Das Göttinger Miniaturschwein. Paul Parey, Berlin \& Hamburg, pp. 44-68.

2. Fischer, R., Sanz, M., Bovet, F., Brechbühler, T. \& Monnier, J. (1953) Journées transfusionelles, Médecine \& Hygiène, Genève, Vol. II, 46-61.

3. Beglinger, R., Becker, M., Eggenberger, E. \& Lombard, C. (1975) Res. Exp. Med. 165, 251-263.

4. Becker, M., Beglinger, R. \& Stauffer, U. G. (1976) Res. Exp. Med. 167, 185-192.

5. Wissenschaftliche Tabellen Geigy, Teilband Hämatologie uñ Humangenetik, 8. Auflage (1979), Ciba-Geigy, Basle, pp. 69-128.

6. Normal Values for Pediatric Clinical Chemistry (1974) Special Publication of Am. Ass. Clin. Chemists.

7. Unpublished data from our controls $(60-100$ healthy children, equal sex distribution).

8. Wissenschaftliche Tabellen Geigy, Teilband Körperflüssigkei= ten, 8. Auflage (1977) Ciba-Geigy, Basle, pp. 229-232.

\author{
Dr. T. Brechbühler \\ Laborleiter \\ Universitäts-Kinderklinik \\ Römergasse 8 \\ Postfach \\ CH-4005 Basel
}

